\title{
Detection of HIV-1 and -2 Antibodies among Selected Secondary Schools in Udenu L.G.A. of Enugu State, South East, Nigeria
}

\author{
Onwuchekwa Augustine Okoli ${ }^{1}$, Charles Chibueze Ezekoye ${ }^{2 *}$ Ogochukwu Ochiabuto $^{3}$, \\ Clemtina Ngozi Nwafor ${ }^{1}$, Stella Ukamaka Ugwu ${ }^{1}$ \\ ${ }^{1}$ School of Applied Science and Technology, Department of Science \\ Laboratory Technology, Federal Polytechnic, Oko, Nigeria \\ ${ }^{2}$ School of Natural and Applied Sciences, Faculty of Biological Sciences, Department of Microbiology, \\ University of Port Harcourt, Port Harcourt, Nigeria \\ ${ }^{3}$ Microbiology Unit, Department of Medical Laboratory Science, Faculty of Health Science and Technology, \\ Nnamdi Azikiwe University, Awka, Nigeria \\ Email: *projectcharles2013@yahoo.com
}

Received November 4, 2013; revised December 4, 2013; accepted December 11, 2013

Copyright (C) 2013 Onwuchekwa Augustine Okoli et al. This is an open access article distributed under the Creative Commons Attribution License, which permits unrestricted use, distribution, and reproduction in any medium, provided the original work is properly cited. In accordance of the Creative Commons Attribution License all Copyrights (C) 2013 are reserved for SCIRP and the owner of the intellectual property O. A. Okoli et al. All Copyright (C) 2013 are guarded by law and by SCIRP as a guardian.

\begin{abstract}
This study was carried out to determine the prevalence of HIV-1 and -2 among three selected secondary schools in Udenu Local Government Area of Enugu State, Nigeria. Three hundred students were recruited for this study representing 120 males (40\%) and 180 females (60\%) with their age ranging from 12 to 20 years from September to November, 2010. Samples of blood were collected and processed using standard laboratory procedures. All the students were screened for the presence of antibodies to HIV-1 and -2 using 2 enzyme-linked immunosorbent assay (ELISA) rapid screening kits, based on WHO systems-2 for detecting antibodies to HIV-1 and -2. The diagnosis of HIV infection was further confirmed by Western blot. The results showed that out of the 300 students who were enrolled into the study, 6 (2\%) were positive for HIV-1 and -2 antibodies including two males ( $0.7 \%)$ and four females (1.3\%). Statistically, there is a significant difference in the distribution of HIV infections by gender $(\mathrm{P}<0.05)$. It showed that students aged 12 years and below 20 years had lower infection rate for HIV. Statistically, there is no significant difference in the distribution of infections with respect to age $(\mathrm{P}>0.05)$. Although its prevalence is low, the presence of HIV-1 and -2 antibodies in Secondary School students of Udenu L.G.A. of Enugu State should be worrisome because it can easily be transmitted to other healthy individuals in the nearest future. Therefore, this calls for a concerted and synergistic effort to nip the spread in the bud so that it cannot spread to other teenagers and the larger community.
\end{abstract}

Keywords: Blood; ELISA; HIV/AIDS; Sero Prevalence; Secondary Schools; Nigeria

\section{Introduction}

Human immuno-deficiency Virus (HIV) is the etiologic agent of Acquired Immuno Deficiency Syndrome (AIDS). The illness was first described in 1981, and HIV 1 was isolated by the end of 1983. Since then, AIDS has become pandemic, expanding in scope and magnitude. HIV infections have affected different populations and geographical regions.

Millions are now infected worldwide; once infected,

${ }^{*}$ Corresponding author. individuals remain infected for life. Within a decade, if left untreated, the vast majority of HIV infected individuals develop fatal opportunistic infections as a result of HIV-induced deficiencies in the immune system. AIDS is one of the most important public health problems worldwide at the start of the $21^{\text {st }}$ Century [1]. The distribution of the virus is global but the incidence rate in the past few years appears to have gone down. Generally, two types of HIV exist, HIV-type 1 and HIV-type 2. They elicit the production of different specific antibodies after infection of an intact host [2]. Different studies to 
determine the prevalence of HIV among different populations have been carried out. Another study, Brodine et al. [3] reported that out of 1050 military personnel screened for the human immuno-deficiency virus in the United States, only 95 were positive. In another study, in the USA, students in 19 universities were screened for Human immuno-deficiency virus. Out of 16,863 students, only $30(0.2 \%)$ were positive to HIV [4]. In a study by Nwachukwu and Orji [5], out of 167 fresh graduates, 8 (4.79\%) had HIV infection and all of them do not have any prior information about their HIV status. Similarly, another study by Mbakwem-Aniebo et al. [6] reported that out of 706 freshmen sero-diagnosed, 6 (0.9\%) were positive for HIV-1 and -2 antibodies. This showed that students aged 16 years and above had higher infection rate for HIV $(15.5 \%, \mathrm{n}=16)$.

In 2008, an estimated 2.7 million (2.4 - 3.0 millions) new HIV infections occurred. It is estimated that 2 million (1.7 - 2.4 million) deaths due to AIDS-related illness also occurred worldwide in 2008. The latest epidemiological data indicate that globally the spread of HIV appears to have peaked in 1996, when 3.5 million (3.2 million - 3.8 million) new HIV infections occurred. In 2008, the estimated number of new HIV infections was approximately $30 \%$ lower.

The first case of AIDS in Nigeria was reported in 1986. The prevalence of HIV in Nigeria in the late nineteen eighties was less than $0.1 \%$, but it rose to about $1.8 \%$ by 1991 and $7 \%$ by the end of 1999. By the end of December 2003, HIV sero-prevalence sentinel survey showed that Cross River State had the highest prevalence of $12 \%$ followed by Benue State (9.3\%), while Osun State had the lowest prevalence of $1.2 \%$ in the country. The government (Federal, State and Local), non-governmental organizations (NGO) and corporate bodies have joined hands in the fight against this disease. This study was therefore, designed to assess the prevalence of HIV among selected secondary school students of Udenu L.G.A. of Enugu State.

\section{Materials and Methods}

\subsection{Study Design}

This was a cross sectional sero-analyses to determine the prevalence rate of HIV infection among Secondary School students from September-November, 2010. The study was carried out in Medical Microbiology and Virology unit, Department of Science Laboratory Technology, School of Applied Science and Technology, Federal Polytechnic, Oko, Southeastern, Nigeria. The student's samples were transported to the laboratory for free retro viral screening. Teachers who were interested were tested but excluded from the study, so as to achieve the specific objectives of the study. A total of three hundred students (120 males and 180 females) of different ages and socioeconomic status were recruited one hundred students (100) from each school. The study was performed according to International Guidelines for $\mathrm{Hu}$ man experimentation in Clinical Research. The age of the students ranged range from 12 - 20 years. The diagnosis of HIV infection was established by standard ELISA and further confirmed by Western blot. Table 1 summarises the demographic characterization of the secondary school students of Udenu L.G.A. of Enugu state, south east, Nigeria used in this study.

\subsection{Methods}

The method of blood sample collection employed was venipunture. The samples of blood were collected into EDTA bottles. The specimens were transported in a commercially available and transport system to the Medical Microbiology and Virology unit, Department of Science Laboratory Technology, School of Applied Science and Technology, Federal Polytechnic, Oko, Southeastern Nigeria, for analysis and processed using standard laboratory procedures All the patient were screened for antibodies for HIV-1 and HIV-2 using 2 enzyme linked immunosorbent assay (ELISA) rapid screening kits, based on WHO systems-2 for detecting antibodies to HIV-1 and 2. A World Health Organization (WHO) approved kits called 'DETERMINE ${ }^{\circledR}$ HIV-1/2 (Abbott laboratories) and HIV- 1/2 STAT-PAK ${ }^{\circledR}$ (Chembio Diagnostic Systems, Inc.)', ELISA based kits, were used for the detection of the presence of HIV-1 and/or HIV-2 antibodies in the blood samples collected,. The kits were designed primarily to test for the presence of HIV-1 and/or HIV-2 antibodies in the blood. This ELISA based kit is both sensitive and specific (99\% - 100\%). The diagnosis of HIV infection was further confirmed by Western blot. All tests were carried out according to the manufacturer's specifications. All data generated was presented in Tables and subjected to statistical analysis (the P2-test, with the level of significance set at $p<0.05$ ) using statistical package for social sciences (SPSS) to determine any significant relationship between infection

Table 1. Demographical characteristics/Parameters of the students in the three selected Secondary Schools in Udenu L.G.A. of Enugu State, South East, Nigeria.

\begin{tabular}{cc}
\hline Parameters & No Tested (\%) \\
\hline Age Group (years) & $300(100.0)$ \\
$12-20$ & \\
Sex & $120(40)$ \\
Males & $180(60)$ \\
Females & $300(100)$ \\
Total & \\
\hline
\end{tabular}


rate, age and gender. The prevalence of HIV was determined from the proportion of positive individuals to the total number of individual under consideration and it is expressed in percentage.

\section{Results}

Of the 300 students who were enrolled into the study, 6 (2\%) were positive for HIV-1 and -2 antibodies, 2 males (0.7\%) and 4 females (1.3\%). There were 120 (40\%) males and 180 (60\%) females, their age ranging from 12 to 20 years. The baseline characteristics of the infected students are shown in Table 2 along with values for the age and sex. The age specific infection rate showed that students 15 - 20 years of age had higher infection rate for HIV than those in 12 - 14 years (Table 2) with values for age and sex. Statistical analysis by chi-square however showed no significant difference in the distribution of infections with respect to age $(\mathrm{P}>0.05)$.

The gender-specific infection rate showed that females had higher infection rate of $4(1.3 \%, n=4)$ for HIV than their male counterparts $(0.7 \%, n=2)$. However, there was a significant difference in the distribution of HIV infection and sex of subjects $(\mathrm{P}<0.05)$.

\section{Discussion}

A total of 300 samples of blood were collected from three selected secondary school students of Udenu L.G.A. of Enugu State between September and November 2010; of which 6 representing 2.0\% were positive for antibodies to HIV-1 and -2. Two male students $(0.7 \%)$ and four female $(1.3 \%)$ students were positive to HIV. As the world enters the third decade of the HIV/AIDS pandemic, the evidence of its impact is undeniable, robbing countries of both human and natural resources. In line with the findings of previous studies, $2.0 \%$ infection rate reported in this study is comparatively low. HIV prevalence among female and male premarital couples in the United States of America was found to be 0.0 to $0.4 \%$ and 0.0 to $1.1 \%$ respectively [7]. The $2.0 \%$ reported in this study is higher than the $0.2 \%$ prevalence of HIV re-

Table 2. Risk factors for HIV infection among the three selected Secondary Schools in Udenu L.G.A., South East Nigeria from September to November, 2010.

\begin{tabular}{ccc}
\hline Parameters & No Tested (\%) & No Positive for HIV (\%) \\
\hline Age group (years) & & \\
$12-20$ & $300(100.0)$ & $6.0(2.0)$ \\
Sex & & \\
Males & $120(40)$ & $2(0.7)$ \\
Females & $180(60)$ & $4(1.3)$ \\
Total & $300(100)$ & $6.0(2.0)$ \\
\hline
\end{tabular}

ported by Gayle et al. [4] among University students in USA and $0.9 \%$ reported by Mbakwem-Aniebo et al. [6] among freshmen of University of Port Harcourt, Port Harcourt, Southern Nigeria. In-line with this study, a relatively low prevalence of HIV among the premarital couples (2.0\%) was also reported by Jeremiah et al. [8]. When compared with the HIV prevalence of $6.1 \%$ among premarital couples in the South-east of Nigeria, the result of this study appears very low [9]. Contrastingly, an HIV prevalence of $2.0 \%$ was recorded among freshmen in this study and this $2.0 \%$ prevalence was only among singles and age group 12 - 20 years $[8,10]$.

The prevalence rate recorded in this study is not in conformity with the research conducted by [11,12]. Although there is a spatial variation in the HIV and AIDS prevalence in Nigeria as some parts of the country are more affected than others, there is no state or community that is not affected. Another study by Nwachukwu and Orji [5], reported that out of 167 fresh graduates, 8 (4.79\%) had HIV infection and all of them do not have any prior information about their HIV status. In Saudi Arabia, in a cross sectional study, it was observed that 6,046 HIV infections were diagnosed of which 1,285 (21.3\%) were Saudi citizens. It was also reported that infections were common among age groups 20 - 24 years [13]. He also reported that at diagnosis, some infected persons do not have prior knowledge of their HIV status.

In this study, the $2.0 \%$ prevalence rate was only among 12 - 20 years of age. This is comparable to the findings of previous studies in some parts of Nigeria and outside Nigeria.

Our findings also compare favourably with Nwachukwu and Orji, [5] who reported that female corps members had higher prevalence of the infection than their male counterparts. Similarly, Laah and Ayiwulu [14] reported higher seroprevalence rate of HIV/AIDS in females than their male counterparts in Nasarawa State, Nigeria. Also Middelkoop et al. [15] showed a high rate of infection among adolescents (Secondary school students) positively associated with increasing age. They reported a high prevalence rate of 5.0\% among 820 secondary school participants aged 13 - 22 years. This is higher than the value reported in this study. The variation here could have been as a result of the difference in the age of the subjects used.

Macpherson et al. [16] reported in Canada that 256, 970 children are sexually active and may not see need for the use of protective devices such as good quality condoms.

In the same vein, Korenromp et al. [17] discovered that HIV-1 in sub-Saharan African has increased the incidence of clinical malaria by $28 \%$ both in adult and pediatric cases. This is in line with the basic knowledge that HIV/AIDS is a disease of debilitation. 
A few studies have however, reported higher prevalence rate of HIV/AIDS in males than among females counterparts $[18,19]$. Data from the United States of America has shown that among youths aged $13-19$ years, $57 \%$ of reported infections occurred among women and $43 \%$ among young men while among youths aged 20 - 24 years, $64 \%$ of reported HIV infections occurred among young men and 36\% among young women [20]. From 2001 through 2005, it has been reported that African Americans had the largest percentage of new cases of Human Immunodeficiency Virus (HIV)/Acquired Immunodeficiency Virus (AIDS) in all age categories, especially among people aged 13 - 24 years [21].

Testing for HIV can serve as a bridge for providing early treatment and encouraging behavior change among people already infected with HIV or at risk of HIV infection [6,21-23]. Enlightenment campaigns on HIV/ AIDS and education programme on safe sex and behavior change among fresh students of university remain key responses to the epidemic $[6,24]$.

\section{Conclusion}

This study has revealed that the prevalence of HIV among selected secondary school students is similar to other studies in other developing areas in the country. Though the prevalence appears to be low, it represents a significant outcome. Hence, those who were infected could spread the infection rapidly especially in the rural communities where governmental health campaign slogans and jingles hardly reach the people. Therefore, this study calls for a collaborative effort of the Governmental and non-governmental agencies of the world to strengthen their campaign against the dreaded HIV/AIDS, as these campaigns should focus on adolescents (secondary school students and university undergraduates), who are the most sexually active groups of our society. Governments of different countries of the world should deploy compulsory HIV screening programmes and health education on adolescent sexual reproductive health and HIV/ AIDs prevention. This will help reduce the prevalence rate of infection to a minimum.

\section{REFERENCES}

[1] G. F. Brooks, S. J. Butel and A. S. Morse, “Jawetz, Melnick and Adelberg's Medical Microbiology,” 23rd Edition, McGraw-Hill, Inc., New York, 2004.

[2] A. Kovas and X. J. Rusheed, "Comparison of a Rapid Non-Isotopic Polymerase Chain Reaction Assay with Four Commonly Used Methods for the Detection of Infection of Human Immune-Deficiency Virus Type One in Neonates and Children," The Pediatric Infectious Disease Journal, Vol. 14, 1995, pp. 948-954. http://dx.doi.org/10.1097/00006454-199511000-00005

[3] S. K. Brodine, R. A. Shaffer, M. J. Starkey, S. A. Tasker and J. L. Gilcrest, "Drug Resistance Patterns, Genetic Subtypes and Features in Military Personnel with HIV-1 Seroconversion,” Annals of Internal Medicine, Vol. 131, No. 7, 1999. pp. 502-506.

http://dx.doi.org/10.7326/0003-4819-131-7-199910050-0 $\underline{0004}$

[4] H. D. Gayle, R. P. Keeling, M. Garcia-Tunon, B. W. Kilbourne and J. P. Narkunas, "Prevalence of Human Immunodeficiency Virus among University Students," The New England Journal of Medicine, Vol. 232, 1990, pp. 1538-1541.

http://dx.doi.org/10.1056/NEJM199011293232206

[5] N. C. Nwachukwu and A. Orji, "Sero Prevalence of Human Immunodeficiency virus among Some Fresh Nigerian Graduates,” Research Journal of Immunology, Vol. 1, No. 2, 2008, pp. 51-55.

http://dx.doi.org/10.3923/rji.2008.51.55

[6] C. Mbakwem-Aniebo, C. C. Ezekoye and I. O. Okonko, "Detection of HIV-1 and -2 Antibodies among Freshmen of the University of Port Harcourt, Port Harcourt, Southern Nigeria,” World Applied Sciences Journal, Vol. 16, 2012, pp. 1087-1092.

[7] L. P. Peterson and C. R. White, "Premarital Screening for Antibodies to Human Immunodeficiency Virus Type 1 in United States: The Prenatal Screening Group,” American Journal of Public Health, Vol. 80, 1990, pp. 1087-1090. http://dx.doi.org/10.2105/AJPH.80.9.1087

[8] Z. A. Jeremiah, I. A. Okon and T. A. Jeremiah, "Seroprevalence of HIV and Frequency of Haemoglobin Genotypes, ABO and Rh Blood Groups, among Premarital Couples in Port Harcourt, Nigeria," South African Family Practice, Vol. 49, No. 2, 2007, p. 15.

[9] O. U. Umeora and C. Esike, "Prevalence of HIV Infection among Premarital Couples in South-East, Nigeria," African Journal of AIDS Research, Vol. 4, 2005, pp. 99-102. http://dx.doi.org/10.2989/16085900509490348

[10] C. I. Akani, O. Erhabor and S. Babatunde, "Pre-Marital HIV Testing in Couples from Faith-Based Organisations: Experience in Port Harcourt, Nigeria,” Nigerian Journal of Medicine, Vol. 14, No. 1, 2005, pp. 39-44.

[11] O. J. Akinjogunla and A. A. Adegoke, "Sero-Prevalence of Human Immunodeficiency Virus (HIV) 1 and 2 Infections in Uyo Metropolis, Akwa Ibom State,” Scientific Research and Essays, Vol. 4, No. 11, pp. 1381-1384.

[12] G. R. I. Pennap, M. D. Makut, S. D. Gyar and G. Owuna, "Sero-Prevalence of HIV/AIDS in Keffi and Environs," Nigerian Journal of Microbiology, Vol. 20, No. 3, 2006, pp. 1114-1146.

[13] T. A. Madani, Y. Y. Al-Mazrou, M. H. Al-Jeffri and N. S. Al Huzaim, "Epidemiology of the Human Immunodeficiency Virus in Saudi Arabia: 18 Years Result and Prevention from an Islamic Perspective," BMC Infectious Disease, Vol. 4, 2004, pp. 1186-1188. http://dx.doi.org/10.1186/1471-2334-4-25

[14] J. G. Laah and E. Ayiwulu, "Socio-Demographic Characteristics of Patients Diagnosed with HIV/AIDS in Nasarawa Eggon,” Asian Journal of Medical Sciences, Vol. 2, No. 3, 2010, pp. 114-120.

[15] K. Middelkoop, L. G. Bekker, H. Liang, L. D. H. Aquino, 
E. Sebastian, L. Myer and R. Wood, "Force of Tuberculosis Infection among Adolescents in a High HIV and TB Prevalence Community: A Cross-Sectional Observation Study," BMC Infectious Disease, Vol. 11, 2011, p. 156. http://dx.doi.org/10.1186/1471-2334-11-156

[16] W. D. Macpherson, M. Zencovich and B. D. Gushulak, "Emerging Pediatric HIV Epidemic Related to Migration,” Emerging Infectious Diseases Journal, Vol. 12, No. 4, 2006, pp. 612-615. http://dx.doi.org/10.3201/eid1204.051025

[17] E. L. Korenromp, B. G. Williams, S. J. Vials, E. Gonwis and C. F. Gilks, "Malaria Attributable to HIV-1 Epidemic in Sub-Sahara Africa,” Emerging Infectious Diseases, Vol. 11, No. 9, 2005, pp. 1410-1419.

[18] AVERT, “HIV and AIDS in Nigeria,” 2010. http://www.avert.org/aids-nigeria.htm.

[19] A. Celikbas, O. Ergonul, N. Baykam, S. Eren, H. Esener, M. Eroglu and B. Dokuzoguz, "Epidemiologic and Clinical Characteristics of HIV/AIDS Patients in Turkey, Where the Prevalence Is Lowest in the Region,” Journal of the International Association of Providers of AIDS Care, Vol. 7, No. 1, 2008, pp. 42-45. http://dx.doi.org/10.1177/1545109707306575
[20] Centers for Disease Control (CDC) and Prevention, "HIV/AIDS Statistics," HIV/AIDS Surveillance Report, Vol. 13, No. 2, 2002, pp. 1-44.

[21] P. E. Thomas, A. C. Voetsch, B. Song, D. Calloway and C. Goode, "HIV Risk Behaviors and Testing History in Historically Black College and University Settings,” Public Health Reports, Vol. 123, No. 3, 2008, pp. 115-125.

[22] Centers for Disease Control (CDC) and Prevention, "Adoption of Protective Behaviors among Persons with Recent HIV Infection and Diagnosis-Alabama, New Jersey and Tennessee, 1997-1998," Morbidity and Mortality Weekly Report (MMWR), Vol. 49, 2000, pp. 512-515.

[23] N. S. Wenger, L. S. Linn, M. Epstein and M. F. Shapiro, "Reduction of High-Risk Sexual Behaviors among Heterosexuals Undergoing HIV Antibodies Testing: A Randomized Clinical Trial," American Journal of Public Health, Vol. 81, No. 12, 1991, pp. 1580-1585. http://dx.doi.org/10.2105/AJPH.81.12.1580

[24] C. Mbakwem-Aniebo, C. C. Ezekoye and I. O. Okonko, "Knowledge about HIV/AIDS and Reported Risk Behaviours among Freshmen of the University of Port Harcourt, Port Harcourt, Southern Nigeria,” World Applied Sciences Journal, Vol. 16, 2012, pp. 1093-1103. 